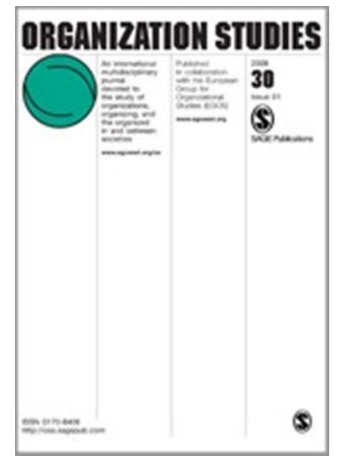

\title{
Tower Cranes and Organization Studies
}

\begin{tabular}{|c|l|}
\hline Journal: & Organization Studies \\
\hline Manuscript ID & OS-15-0733.R2 \\
\hline Manuscript Type: & Essai \\
\hline Keywords: & $\begin{array}{l}\text { tower cranes, materials, construction, socio-technical, Futurism, } \\
\text { Constructivism }\end{array}$ \\
\hline Abstract: & $\begin{array}{l}\text { This is a paper about different ways of revealing materials, and a theory of } \\
\text { organization. It moves through a kaleidoscope of perspectives which reveal } \\
\text { the tower crane as made through its relations with a series of different } \\
\text { ways of seeing - engineering and mathematics, capitalist economics, and a } \\
\text { workplace labour process. It employs a wide variety of sources, including } \\
\text { some interviews that I have done with crane drivers. I then move into an } \\
\text { account of the modernist fascination with technology, particularly Soviet } \\
\text { Constructivism. The latter provides the theoretical scaffolding which allows } \\
\text { me to see the crane as a temporary stabilisation of structure, and structure } \\
\text { as an arrangement of planes and lines of force which allows certain moves } \\
\text { just as it prevents others. This is a way of saying that an adequate } \\
\text { understanding of 'organization' requires thinking multiples and relations. } \\
\text { Nodding towards Deleuze and Guattari towards the end, I suggest that } \\
\text { cranes are good to think with for these multiple purposes, but that any } \\
\text { assemblage would do. }\end{array}$ \\
\hline \hline
\end{tabular}




\section{Tower Cranes and Organization Studies}

'The subject of this Treatise is the construction and use of machines which diminish toil, and facilitate and lessen labour without superseding it; enabling men to perform what they could not accomplish without such aid.' Joseph Glynn Rudimentary Treatise on the Construction of Cranes and Machinery (1849: v)

'Let us open up the figure like a window and enclose within it the environment in which it lives.' Umberto Boccioni, Technical Manifesto of Futurist Sculpture (1912)

The puzzle that motivated this speculative paper begins with the strange double life of the tower crane $^{1}$. In any large city they are ubiquitous. Solid and gigantic structures of steel, bristling on a bustling skyline; swinging over the streets. Even children know about cranes, and many may well possess one. A toy in yellow plastic, or one with a face on, like Cranky the Crane from Thomas the Tank Engine. Cranes are just too big to miss.

The word comes from the Old High German krano or kran for a large wading bird, perhaps an echo of its cry across the flat wet marshes. The use to mean a 'machine with a long arm' is first seen in the late $13^{\text {th }}$ century, followed by the extension to the human body ('craning your neck') as a verb at the beginning of the $19^{\text {th }}$ century. Like many words and their associated concepts, the etymology documents mutability - from sound to animal to machine to the human body. This is suggestive, because despite the solid clarity of their existence, cranes are curiously ephemeral objects, lacy sketches of lines which can disappear overnight, unnoticed, and materialise somewhere else a few days later. You can see the sky through them, or the structures that they grow next to them, before they vanish like embarrassed parents or guilty lovers. And, unlike the buildings themselves, the pride and joy of city boosters and the object of glossy books - the light bouncing off their arrogant glass and stone surfaces - the cranes have been folded away from history. Almost no-one writes about cranes, apart from instruction manuals or professional magazines. Almost no-one makes art with them ${ }^{2}$ or music about them or dances for them. They are modest giants, hiding in the light.

Almost no-one. In Eva Weber's beautiful documentaries 'City of Cranes' (2007) and 'The Solitary Life of Cranes' (2008), tower crane drivers sit in their cabs impassively observing the city below. As the sun chases the shadows of the buildings, the crane makes its episodic moves, a chess player with steel. Like the watchful angels in Wim Wender's haunting film 'Wings of Desire' (1987), or a superhero standing on the ledge of a skyscraper with their cape fluttering in the wind, the operators look down on the bustle. Their hands twitch on the two tiny joysticks and far away and below, motors purr and cables whine whilst the wind makes the crane twitch and buck. What can they see from up there? What perspective does such elevation provide? Do they imagine themselves to be gods, or are they stuck there, dreaming of being down here, with us?

From the perspective of organization theory - understood generously - these reflections matter because the crane is so clearly part of the sociotechnical assemblages of the modern world. As we will see, its manufacture, mobility, economics and operation are all staggeringly complex and necessarily global. The crane is one element in the entangled processes that make the modern city, as well as the power plants, bridges, container ports and electricity pylons that allow the city to live. 
The crane stands at the heart of these systems, and I want to use it here as an object which allows me to unfold the movements of the world around it. I want to show that the crane makes, and is made. One of Bradley Garrett's 'place-hackers', or 'urban explorers', looks down from a crane across London at night at and comments that, like the river, 'it's all flow' (2014: 84). A century before, Umberto Boccioni, an Italian Futurist, suggested that any entity can be treated like this, as a temporary stabilisation of that which surrounds it. He goes on -

'No one still believes that one object finishes off where another begins or that there is anything that surrounds us - a bottle, a car, a house, a hotel, a street-which doesn't cut into and sectionalize us with its arabesque of curves and straight lines.' (1912: 115)

This is a relational ontology, one in which the object, the material is always and necessarily part of that which surrounds it. It is also an organized world, but not simply in the sense of being a world of organizations (though that is not so far from the truth either). What I am exploring in this paper is the idea that we can reveal the processes of organizing in this more general sense by trying to understand the various ways in which the crane is revealed (despite its persistent tendency to disappear) through different lines of sight as a topic of engineering, economics, labour, and aesthetics. These are not separate matters, but more like different ways of making something visible in different ways, or making different visibilities possible from the same materials ${ }^{3}$. The philosopher Henri Bergson, who had some influence on the Italian Futurists, as well as contemporary organization theory (Hernes et al 2014) was keen on this sort of relational understanding -

'Does not the fiction of an isolated object imply an absurdity, since this object borrows its physical properties from the relations which it maintains with all the others, and owes each of its determinations, and consequently its very existence, to the place which it occupies in the universe as a whole?' (Bergson 1911: 11-12).

I will return to what this suggests about the ontology of cranes, and a theory of organization, in the final section of the paper. First, I want to move through a series of perspectives which reveal the crane as borrowing properties from its relations with a series of different ways of seeing engineering and mathematics, capitalist economics, and a workplace labour process. Along the way, I will be using a variety of sources, including some interviews that I have done with crane drivers. In order to synthesise these different accounts, I then move to aesthetic perspectives, particularly Italian Futurism and Soviet Constructivism. The latter provide the theoretical hints which allow me to see the crane as a temporary stabilisation of structure, and structure as an arrangement of planes and lines of force which allows certain moves just as it prevents others. These aesthetic ideas allow me to present a relational ontology which encourages us to think that different ways of seeing produce different objects (Mol 2003). Concluding by borrowing some ideas from Deleuze and Guattari, I suggest that cranes are good to think with for these purposes, but that any assemblage would do.

A caveat, before I begin. This is mainly a piece about tower cranes, because they are the ones which have fascinated me, but they are only one amongst many types of cranes. Indeed, if you read glossy magazines like International Cranes and Specialised Transport or Cranes Today you will see that tower cranes are a small part of a large industry. However, in this paper, I'm not really concerned 
with all terrain cranes, crawler cranes, mobile cranes, harbour cranes, gantry cranes, cable cranes or sky-cranes (see Bachmann 1997). Many of the arguments I make below might be applied to them, or illustrated with them, but they aren't the ones that have elevated my imagination here. For those we must slew back to the beginning, to a thoughtful man eating a sandwich in a tiny cab, while below him the networks of the city gradually illuminate in the gathering gloom.

\section{Engineering}

'If man were furnished with no other means of defence, or of assistance to his physical strength, than those which his own organization supply, he would be one of the most helpless creatures existing. (...) The pole in his hands becomes a lever to remove the trunk of the fallen tree, and the rope of twisted thongs or fibres of bark, thrown over the fork of an extended branch, probably formed the first crane.' (Glynn 1849: 1)

It's all very well being romantic about this man, alone with his intensity, his perspective, his power, while the wind circles his lonely dwelling ${ }^{4}$. It feels like one of those Caspar David Friedrich paintings on the front cover of a paperback by Nietzsche, in which the hero reflects on mountain tops and fears nothing, apart from mundanity. Meanwhile, the masses chatter around in the streets like ceaseless insects, never looking up. But you wouldn't hear an engineer talking like that, any more than Neil Armstrong could write poetry about landing on the moon (Mailer 1971).

A tower crane is an engine on stilts. To make one, you need a lot of steel, as well as bolts, washers, gaskets, welding gear, presses, wiring, bearings, anti-corrosion paint, hydraulic rams, tubing, steel cables, glass, printed circuit boards, concrete counter weights and so on. Imagine placing your hand on the base of a crane and feel the cold materiality of metal and the vibration of motors making the structure shiver slightly, and creak as it responds to wind and stress. The contemporary language of cranes is not the language of the romantic sublime, but of the technologies of the material. The operator hoist, pipe grabs, manriding cage, automatic hook, Ultraview cab, Manitowoc Crane Control System. They are made by companies with names that might be familiar from illuminated signs hanging over cities - Potain, Linden Comansa, Wolffkran, Liebherr, Terex, XCMG - but could be global corporations that do pretty much anything. There is an older language buried there too, one that echoes its nautical origins (Glynn 1849: 9, Bachmann 1997: 65). Cranes have spreader beams, spars, jibs, slings, shackles, booms, and rigging. They slew and luff, and their ropes reeve, they have outriggers and ballast, and they sometimes oversail properties.

The first structures that look anything like modern tower cranes were permanent hammerhead port cranes at the beginning of the $20^{\text {th }}$ century. Gigantic constructions of steel with names like 'Titan', 'Ajax' and 'Hercules', these were built to last and stay in one place. When the tower crane moved inland to construction sites a decade or so later, it was in a much more slender form which allowed it to be moved from site to site. Even so, the problem of assembly and disassembly wasn't really solved effectively until the 1950s, when German manufacturers took the lead in providing machinery for post-war reconstruction. Oddly perhaps, despite the building of skyscrapers in North America from the early $20^{\text {th }}$ century onwards, tower cranes were first used on European building sites. The Empire State and the rest had been built with derrick cranes and hoists attached to the structure, combined with a great deal of cheap labour. Thirty years later, in Europe, the rise of modernist tower blocks that soon surrounded war damaged cities meant that the market for the manufacture and hire of tower cranes boomed. The invention of the self-jacking crane, which could insert sections 
into its tower, or the crane which could move up inside a lift shaft, meant that construction could be fast and require less labour. Effectively, the tower crane becomes mobile, a temporary structure which could move between sites. By the 1980s, this was becoming true on a global scale, as tower cranes became engineered to fit into shipping containers in order to follow the tides of the construction industry to Sydney, Shanghai and Dubai.

It's not enough to imagine that this engineered metal is the bottom line of the crane though, because underpinning all this is the mathematics of weight, mass, stress and angle. In a book on cranes from the middle of the $19^{\text {th }}$ century, Joseph Glynn is at pains to note that the angles of materials and distribution of stress should not be understood through mere experience (though he recounts a fair amount of that) but through tables and calculations. To begin, to understand how a crane works at all, we need to understand what a pulley does, and hence what combinations of pulleys do. Second, we need to know that lifting a weight causes stresses in materials, and the nature of these stresses depends on the material, and on its angles and bracing.

Glynn, in his Rudimentary Treatise on the Construction of Cranes and Machinery, provides us with a table which shows weights raised, time taken, the resistance of the handle and different sorts of men, in order to come up with an assessment of the power of different men. So $11550 \mathrm{lbs}$ was raised by one foot in one minute 'easily by a stout Englishman', whilst 15134 lbs was achieved 'with the utmost exertion by a Welshman' (1849: 27). His book proceeds from such simple experiments with 'man-machines' to more complex calculations of the strength of wood and metal in different configurations, the difference between compression and transverse stresses, the power and problems of hydraulics. This leads us into a different language, that of mathematics, and the sort of alchemy which compares the strengths of cast iron, wrought iron, cast steel, Dantzic oak and red deal in order to understand the relative breaking weight of solid columns, expressed as $W=$ $44.16 \frac{D 3.16}{L 1.17}$, and hollow columns, expressed as $W=44.34=\frac{D 3.6-d 3.6}{L 1.7}$.

'From what has already been stated, it is evident that all crane jibs, acting on the thrust, should have their diameter largest on the middle and tapering in a curved form, approximating to the parabolic, towards the ends, which should be about 2/3 the diameter of the middle, and also in order to obtain the greatest strength with the least material, in a cast iron crane job, acting on the thrust, it should be made hollow, and the ends should be fixed, so that the stress shall be taken directly through the axis of the pillar, or that the ends of the pillar shall be flat, and their planes at right angles with its axis.' (op cit: 69)

Glynn also reports the experiments of others, such as the late Mr. John Kingston, in the dockyard at Woolwich and reported in 'all their details in the Transactions of the Society of Arts, Volume 51, 1837.' (op cit: 71). Founded in 1754 as the 'Society for the Encouragement of Arts, Manufacture and Commerce', the Transactions began to be published annually from 1783 and contained articles usually classified under the headings 'Agriculture: Including Planting, Gardening and every Branch of Rural Economy', 'Manufactures', 'Chemistry and Minerology', 'Mechanics: including Hydraulic, Pneumatic, Optical, Mathematical, Astronomical, and Surgical Apparatus', 'Fine Arts', 'Colonies and Trade'. Volume 51 appears to be missing, but volume 52 (part one) contains articles such as 'Instrument For Ascertaining The Stability Of A Ship', 'A Resonant Spring For Table-Clocks', as well as 'Marble Tablets For Miniature Painters', 'Making Casts from Soft Anatomical Specimens' and a paper on 'Hoeing Wheat'. Glynn (1799-1863) was elected a fellow of the Royal Society of Arts in 1838, and 
was famous for designing steam engines, particularly naval engines, as well as a machine for draining the marshy fens in Eastern England.

The expertise that Glynn cultivated, and that was documented in the Transactions, was a practical and cumulative knowledge that intended to displace the experience of the hand and eye with the language of engineering. The connection between experiment and mathematics would lead to the making of new relations, and hence of new possibilities. To lift a weight - to change the relations between one material and another - required that a configuration of energy and materials is tested until it fails, and that failure is then treated as a limit condition for further experiments. But that isn't enough, because (as the categories of the Transactions indicate) there were some further conditions commonly required to motivate such experiments - 'manufacture', and 'colonies and trade'.

\section{Economics}

'In every state of society the many must be ruled by the few, and "those who think must govern those who toil;" but the relations of society in this country at present have the effect of increasing wealth in few hands, and many men labour to make one man rich.' (Glynn 1849: vii)

When you start reading magazines and websites such as International Cranes and Specialised Transport, Cranes and Access, or Cranes Today, you enter a dizzyingly global world. A Shell oil production platform in the Philippines, a partnership between a Belgian and a Chinese company, a flare stack in Saudi Arabia, a bridge replacement in Sydney, a gas turbine in South Africa. This is a world underpinned by engineering, but there are almost no stress equations or experiments here. Instead we have accounts of particular challenges, because of difficult terrain or weather, and the hardware choices that were made in order to solve these problems. In 2015, the Cambambe hydroelectric power station on the Kwanza River in Angola was having its dam raised by 20 metres. This required two Linden Comansa 21LC750s with a load capacity of 48 tonnes, and one 21LC400 which can carry 18 tonnes $^{6}$. Angola's record of imprisoning anyone who criticises the ruling party the MPLA - is not mentioned. In the same year, over 30 tower cranes were being used to build a $\$ 5$ billion 'Olympic' complex in Turkmenistan, which will be used for the 2017 Asian Indoor Martial Arts Games. It will have seven indoor arenas, hotels, restaurants and an athlete's village together with a $5 \mathrm{~km}$ monorail to join them together. The personality cult which underpins this dictatorship is not mentioned in the article, though the 350 tonne roof truss of the velodrome merits some attention (Sleight 2015).

It's almost as if the politics - of oil refineries, expensive apartments and dams - becomes imperceptible from a crane. There are engineering challenges stimulated by flows of demand for cranes and hence of money. It is the money that allows the engineering to happen, the money that erects cranes and moves steel and concrete. Finance and engineering are not separate, but absolutely conjoined in the sense that no money could be made if the engineering wasn't right, but very little engineering could be done if the money wasn't there. The equations that explain the relationship between load and stress are parasitic on the equations that calculate the daily costs of crane hire, as well as assembly, disassembly, transportation and storage, and the hourly rates and productivity of the human beings who sit in cabs, drive and load trucks and transporters, maintain equipment and sit in offices making calculations about logistics and profitability. There are intersections with other numbers here too, because cranes can only do their work if the wind is not 
too strong, so it is sensible to ask how many days might they not be productive. Such a calculation will require that a connection be constructed between meteorology (with its alchemy of observations and probabilities) and actuarial science (with its alchemy of observations and probabilities) in order to come up with an insurance cost which is low enough to allow for the possibility of profits but comprehensive enough to ensure that failure doesn't destroy a series of entangled organizations. The numbers all intersect, as they must, in order that a crane can grow.

The language of cranes is a commentary on big construction projects across the world, and on the particular economic circumstances, tax breaks and incentives that might result in the need for cranes. For example, in the July 2015 issue of International Cranes and Specialised Transport the editor bemoans the fact that the government of the UK have withdrawn incentives from wind power. This is expanded upon in an article later in the magazine in which it is asserted that the change is bad because there will be less need for cranes to erect turbines, and about 3000 days of crane rental will be lost. In the same editorial, just a paragraph above, the European 'stage $V$ engine emission regulations' due to be implemented in 2019 are bemoaned as 'the destruction of the mobile crane manufacturing industry here in Europe'. Cranes need big engines, and retrofitting them to ensure that exhaust emissions are within tolerance, or buying new machines, will place too big a financial burden on crane hire companies. The environmental contradiction is not remarked upon, perhaps because the logic that ties the stories together is that the encouragement of cranes is the only good. Cranes mean progress, growth, development - and crane money flows when these things happen. The language of cranes is futurist, conjuring a vertical world of skyline urbanism, power transmission, global operations and mega-projects.

It is often enough said that the number of tower cranes in a city is an indicator of economic prosperity. In fact, there isn't one index, but many, and most are produced in order to underpin the urban boosterism which hopes that one crane (the bird a symbol of good luck in Asia) will give birth to a whole colony. National and regional crane indices show that they migrate around the world, itinerant labourers selling their services to whoever pays most at the time, then moving on when the money runs out. So certain cities gain temporary reputations as fertile grounds for forests of cranes - Berlin after unification, Moscow after the USSR, Tokyo before the lost decade, Shanghai and Beijing after capitalism grew Chinese characteristics, Dubai after oil, Dublin before the tiger caught a cold, and (at the time of writing) London. The speculative boom in residential property by the Thames has encouraged at least one company to produce a crane survey as a way of both marketing London and selling its consultancy products (Deloitte 2015). Deloitte Touche Tohmatsu Limited is headquartered in New York, and had a revenue of $\$ 34.2$ billion in 2014. Its New Street Square headquarters in London houses around 10 thousand people, and is in a complex of buildings of up to 19 stories owned by Land Securities. This mixed use development is worth in excess of $£ 200$ million, and generates $£ 32$ million a year in rent ${ }^{7}$. Land Securities occupies a nine storey building a mile away in London, and in 2015 had an income of $£ 2416$ million from controlling 6.9 million square feet of office and retail property in London alone. Money moves cranes, including cranes to build buildings for companies that encourage the developments that require cranes. One of my crane driver interviewees estimated that in $2015,80 \%$ of UK tower cranes were in London. Another said that, on a recent trip down the Thames, he counted 200 cranes on the riverside alone.

Globally, the International Cranes share index lists 12 major manufacturers and consolidates the movements of their shares into a measurement of the highs and lows of the crane market. Bear in 
mind that these are manufacturers, not rental companies, but the currencies are instructive. Four are priced in Chinese Yuan, three in Japanese Yen, two in Euros, two in US dollars and one is priced in Singapore dollars. As with skyscraper construction in general, the old North Atlantic heartlands have now been largely supplanted by a new global geography around the Pacific. What is happening in London and Lisbon is dwarfed by developments in Guangdong and Bangalore. This can be further evidenced by the decline of docks and shipbuilding, with famous old dock cranes - the Armstrong Mitchell in the Arsenale in Venice, Samson and Goliath in Belfast, the Kockums crane in Malmo, the Finnieston Crane in Glasgow, Titan in Clydebank - now dissembled or left as rust-porn monuments to industrial history.

The crane manufacturer Zoomlion claims in its advertising that 'The bigger we think, the higher it stands'. Height and scale are here employed as metonymic of ambition, of striving and craning your neck to see what the next challenge might be. But the cranes are mercenaries, they will work for the highest bidder, and what they build is less important than the fact that they must keep building. They must always keep moving, or they will rust and die. The skyline of tower cranes - the exoskeleton of capitalism - shows us slewing towards a future of high-rise high-finance, but what happens if we zoom in, to see the person in the cab, hands twitching, bladder straining.

Labour

'The author has for many years had the direction and management of men in considerable numbers. He is convinced that perfect order, strict discipline, and prompt obedience, are imperatively necessary to insure success in the combined effects of many men...' (Glynn 1849: vi)

The crane is the fulcrum around which any construction site is anchored, with the turning circle and hook height of the crane describing the limits of the site. The easiest way to paralyse a large construction project is hence to take over the crane at the beginning of a strike. It ensures no heavy materials can move onto or around the site, and hence prevents many trades from carrying out their work at all ${ }^{8}$. Other people have occupied cranes too - anti EU protesters and 'Fathers for Justice' in London, Greenpeace protesters on a nuclear power station construction site in Finland, migrants in Italy (Oliveri 2014), and South Korean labour activist Kim Jin-suk, who spent 309 days on crane No. 85 at a Busan shipyard in $2011^{9}$. Thirty five metres above the ground, she was demanding workers' rights and the reversal of Hanjin Heavy Industries \& Construction's plans to lay off around 400 employees. She occupied the same crane as Hanjin union leader Kim Ju-ik who hanged himself after 129 days of protest against massive layoffs by the same company in 2003. Kim Jin-suk was a 51-yearold former welder. She slept in the crane's cab, used a bucket for a toilet, and dealt with sub-zero temperatures, a typhoon, a heat wave and monsoon rains. After coming down, she gave an interview to a Korean journalist -

'Kim even said she threw up as if like her daily job. Crane was not a stationary house. It was a space which shook incessantly by the wind. At early times of protest, she threw up as if like a seasick all the time. ${ }^{10}$

In July 2011, more than 7,000 people rallied in support of Kim's sit-in, arriving in a caravan of about 185 'Hope Buses'. In October, she spoke by mobile phone to the Occupy Wall Street protesters in Zuccotti Park - 
Brave citizens of Wall Street, the center of world capitalism and the heart of neoliberalism. This is crane no 85 Hanjin Heavy Industries and Construction in Busan Korea. I occupied this crane last January 6 and has spent 277 days here since then. (...) You OWS demonstrators who fight at Wall Street, New York actually demonstrate things like these are not limited only to Korea but are pains shared by people all around the world. Although the workers of Hanjin Heavy Industries who fight with me are far away from you, we believe the cause we fight for and the world we want to live in would be the same. A society where labor is respected and human beings come before money. Our dreams are the same.

Being a crane driver is a hard job for ordinary pay. It involves boredom and long climbs on freezing ladders, safety and mechanical checks, keeping ladders and work areas clear and not dropping waste from the crane, wearing a rucksack on your front when climbing (not the back), not turning up drunk or using mobile phones, taking rest breaks, having appropriate medical checks and always watching wind and weather conditions (CPA 2008). If the wind gets high, the driver can decide to leave the cab, and allow their cranes to 'weather vane' like Alexander Calder's mobiles, slewing freely to follow the gusts. Crane drivers have to arrive earlier than others on the site, and leave later. Drivers sometimes don't see their co-workers for the entire day, only talking to a few of them on walkietalkies, and have a reputation on the site for being fat and lazy as they sit 'hunched forward, neck bent, leaning heavily on hands, arms and shoulders, trying to see downwards, looking between the legs and through the floor of the cabin' (Dahm 2015: 17). An UK crane driver activist told me that suicides and depression were high amongst drivers, in part because they have so little human contact. One driver told me that he finds himself 'less inclined as years go by to venture forth into large group settings and have almost no desire to participate in the day to day happenings of the majority of my coworkers. The longer I spend doing this job the greater the isolation feels.' It's a dangerous job too. In September 2006, Jonathon Cloke fell to his death from inside the cab of his London crane when it overloaded and snapped ${ }^{11}$. Isherwood (2010) identified 86 incidents involving the collapse or major structural failure of a tower crane in the world between 1989 and 2009.

When I talked to crane drivers, they almost all began by insisting that it was just a job for 'lever pulling monkeys'. As one said on a Facebook site for drivers, all they do is 'pick stuff up, put stuff down.' Sometimes they seemed puzzled as to why I would want to talk to them at all, asking them what they did and whether they gave their cranes names ${ }^{12}$. But then they would tell me stories about the 'lunatics' that they knew (because all drivers are, apparently) and the things that they had done and seen. I heard about a crane bucking violently when its load slipped and a cup of coffee ricocheted around the cab, metaphors of boats in rough seas or roller coasters to explain the movements of the cab, views of naked people and sex through windows, and pissing in a bottle so that you didn't come down for break time. (Because it takes ten minutes to come down from an average crane and the site manager will often pay drivers in extra hours or cash if they don't take their breaks.) That means that drivers might cook toasted sandwiches in the cab, and watch DVDs to pass the time. And when they do finally come down, sometimes the world keeps swaying for a while before the seasick driver gets their land legs again.

And then there was something else, towards the end of the interviews. When the composer Donnacha Dennehy was researching for his piece 'Cranes', he visited a school for crane operators on the outskirts of Dublin. Dennehy asked an operator what he enjoyed about his job. The man responded by saying that when he ascended the massive collection of ladders he left all the troubles 
of his life down on the ground and could 'watch the whole world go by'. ${ }^{13}$ That sense of being 'out of all the silly politics' was common. You see 'how life goes on ... you don't see it normally because you're part of it'. Isolation is sometimes 'a blessing' because it's 'nice and quiet' up there.

Sometimes kids notice you, and wave, coming back day after day, but most people just don't see you at all (Garrett 2014: 84). There is perspective at the top of a crane. As Eva Weber put it, after making her documentary -

'...in many ways it has been the small observations of the drivers that have really stuck with me: the way people walk differently at certain times in the day, the different way couples look before and after a long and stressful Saturday afternoon shopping trip, or the way office buildings in our financial districts change at night--whereas during the day, mirrored glass keeps the outside world out, you can suddenly see clearly inside at night. ${ }^{14}$

Other creatures use the tower too. Bees sometimes build nests which need to be smoked off before the crane can run. In Australia, green snakes and possums have been spotted on cranes, and birds are common. I was told about magpies, red kites, a peregrine falcon, and in Australia a sulphur crested cockatoo. Some drivers live with the birds' nests for months, watching baby crows learn to fly, others destroy the nests before the birds have a chance to lay their eggs in places that might be disturbed by the movement of the crane. And drivers sometimes took pot plants up their cranes, Petunias for one, as if they needed to take a piece of earth up with them.

There are other things too. Watching the sun come up and the sun go down over cities and coasts, and seeing storms roll in and the clouds go green with electric fire. Days when you are above the clouds, alone. Drivers would mention such things, but then retreat to something else. Like astronauts, they wouldn't (or couldn't) share what they knew. As a journalist who responded to Eva Weber's film put it, 'I will look with absurd new respect at these men and women, when they return to earth. They will walk into pubs for cold beers like mortals, but they have touched rare serenity.' (Ferguson 2008). One driver told me to read Jack Kerouac's 1959 novel The Dharma Bums to explain what it was like up there. The story's protagonist spends a summer alone fire watching in a shack at the top of Desolation Peak in Washington State. 'And it was all mine, not another pair of human eyes in the world were looking at this immense cycloramic universe of matter.' And, after months of solitary reflection, as he leaves the shack 'I turned and knelt on the trail and said 'Thank you, shack.' Then I added 'Blah,' with a little grin, because I knew that shack and that mountain would understand what that meant, and turned and went on down the trail back to this world.' (2007: 196, 204). Being a crane driver is just a job, but it can never be just a job, any more than a crane can be just a crane.

\section{Aesthetics}

'We feel mechanically, and we sense that we ourselves are also made of steel, we too are machines, we too have been mechanized by our surroundings. The beauty of transport wagons and the typographic pleasure of solid thick advertising signs, trucks shuddering and trembling of a TRUCK, the fantastic architecture of a construction crane, lucid and cold steels.' Manifesto of Futurist Mechanical Art, Pannaggi and Paladini, 1922 (in Rainey et al 2009: 272)

The beauty of a crane doesn't only have to be understood as some echo of the natural sublime, an elevation to a landscape that stimulates the deep human interior. The modernists of the early 
twentieth century were fascinated by the machine age, not the pastoral, by the sharp angles of a city and the way in which the speed of a bicycle or train dissolved solidity into endless echoes of movement. The groups themselves were as turbulent as their subject matter - Italian Futurists, French Cubists and Orphists, British Vorticists, Russian Futurists, Constructivists, Suprematists, Productivists, and Rayonnists - all insistent that they had the manifesto and methods to capture the modern in ways that others couldn't.

The Futurists, with Filippo Tommaso Marinetti as their impresario, occupied a 'dream-world of trains, planes, submarines and great cities', an attempt to render 'universal dynamism' in painting, poetry, film, architecture (Tisdall and Bozzolla 1996:33). Work and industry were central to futurism, in a way that they never had been for the impressionists. An early example, Giacomo Balla's (1904) 'A Worker's Day', is a Pointillist illustration of the play of light on scaffolding and a pile of bricks around a building under construction. Five years later, referencing Bergson's new philosophy of flux and movement (which had been translated into Italian in 1909), Umberto Boccioni's painting 'The City Rises' (1910) showed a backdrop of smoking chimneys and houses again surrounded by scaffolding, or in 'States of Mind II: The Farewells' (1911) we see pylons, cranes, gantries, all emerging out of railway station smoke. The cross-hatched silhouette of a girder structures Robert Delaunay's 'Eiffel Tower' series (1909-12) or the painting 'Milan station' by Carlo Carrà (1910-11). At the same time architects like Antonio Sant'Elia and Mario Chiattone were producing line drawings of buildings and imaginary cities, almost all never built, with scale, elevation and the girder motif repeated on bridges, towers and decoration.

Italian Futurism might have ended with the cleansing of war, but its fascination with technology echoed into Soviet post-revolutionary art. Not always cranes, of course, but the disciplined angles of pylons, radio towers, and scaffolding shrouded in smoke or stark against the sky. Kasimir Malevitch's Suprematist phase - see for example 'House under construction' (1914-5) - abstracts movement into blocks of colour. Or, perhaps most famously, Vladimir Tatlin's 'Monument to the IIIrd International' (1919-20), an unbuilt tower for Petrograd which was intended to be higher than the Eiffel tower. A spiral of naked steel and glass, projecting words onto the clouds. Height and metal repeat throughout Soviet art, particularly in terms of the radio tower - see, for example, ShassKobelev's 1925 'Lenin and Electrification' poster, or László Moholy-Nagy's 1928 photograph of a Berlin radio tower. The railway station roof and crane are both featured as backgrounds to muscled workers in Yury Pimenov's 'Give to Heavy Industry' of 1927. A few years later, lakov Chernikhov's 'Architectural Fantasy: View of the enormous portal cranes with semi-circular corbels' (1932-1936), makes gantry cranes into gothic arches in front of a blood red sky.

Whether in stage sets, photomontage, mobiles or graphics, much of the art of the first third of the twentieth century was captured by the modern, and its materialization in structures of crosshatched steel. In England, Stephen Spender's poem 'The Pylons' (1933), the march of electricity distribution networks -

'... dwarfs our emerald country by its trek

So tall with prophecy

Dreaming of cities

Where often clouds shall lean their swan-white neck.'

The phrase 'pylon poets' (or 'pylon boys') was coined to refer to these younger left wing poets Auden, Day Lewis and MacNeice - who turned to skyscrapers, aeroplanes, roads and power stations 
to celebrate a modern, democratic aesthetic. The pastoral is replaced by something non-human, but to which the future has been granted. In Cecil Day Lewis's poem to Auden, 'Look west, Wystan, lone flyer' (1933), the 'ascetic pylons pass/bringing light to the dark-livers, charged to deal death'. There are shadows of violence here, as there were with the Italian Futurists from the inception, but this is art which, for Day Lewis, points to the future, to 'a new kind of power, like the pyloncarried wires of which Spender writes' (in Purdon 2013: 25). This uncompromising modernism echoed through le Corbusier's architecture, the Russian émigré Louis Lozowick's images of factories and bridges in the USA in the 1920s and 30s, the engineer Calder's mobiles, to the science fiction streamlining of the 1950s, and the Soviet and NASA rocket gantries of the 1960s. The crane is always there at the birth of the new, it assembles the future.

Donnacha Dennehy's (2010) 'Cranes', a piece of jaggedly relentless modern music, was first imagined as a live orchestral performance with the choreographed movement of cranes located at various building sites across the Dublin skyline during the apex of the construction boom ${ }^{15}$. It never happened, because the construction stopped and the cranes took flight. Listening to it now, it is a modernism of a future that never happened, an attempt to capture a kaleidoscope of movement, an aesthetics which represents ceaseless mobile relations. Cranes promise, but they are designed to disappear, always seeking something newer. How can we think such mobility?

\section{Ontology of cranes}

'When you've got four or five or six cranes together, you've got this wonderful sort of drop in, almost nodding politely to each other and then pulling back and turning round. It's wonderful, and if you are part of it, it's almost like a ballet. But nobody is too arty and if you said it's as though we're in a ballet, you most likely get a rude answer over the radio, and fair enough, fair comment. They think he's not a ballet dancer, he's a crane driver.' Tim, a crane driver ${ }^{16}$

Cranes are everywhere in the Global North, but most people rarely think much about them. They appear in the first episode of the UK TV cartoon 'Mary, Mungo and Midge' in 1969 and in toy and model shops all over the world. We can watch YouTube videos of cranes collapsing, or lunatic free climbers in masks taking selfies as they hang over cities at night (Garrett 2014). The James Bond film 'Casino Royale' (2006) begins with parkour on cranes, and 'Men in Black 3' (2012) has a fight on an Apollo rocket gantry. Yet the crane is almost never a topic in its own right, apart from for those who make them or work with them, like Tim, who refuses to dignify his labour with balletic metaphors. Cranes are always in the background, props for the modern urban mise en scène, curiously absent from thought despite their ubiquity. The things that they construct are solidly visible, the manifestation of architects' imaginations and the financial desires of developers. Buildings are things, surfaces in space that reflect light and define space. Cranes suggest a different ontology, different lessons to teach us about organization, mobility and process. Perhaps, contra Rorty, we might use them as a 'skyhook' to see things differently (1990: 2).

Looking at a crane, you can see structure. Lines of steel, bracketed and bolted to produce angles which direct lines of force, making some moves possible, and others impossible. (If we discount failure, fracture and collapse.) Structure, in its simplest mechanical sense, constrains movement. Seeing structure, having structure revealed, allows the viewer to understand what is possible and what is not. We can see the degrees of freedom in the skeleton. So let's think the crane as a pure structure. Structure can then be conceived as a series of articulations, of joints which allow lines to intersect with planes. When we speak of social structure, such metaphors are rarely made visible, 
but might be made more apparent when the surfaces are stripped away. Perhaps this is why buildings always look more exciting when they are under construction, when you can see the steel, the floor plates and the sky, and watch the transitions as they take place (Garrett 2014: 87). Once they are clad and complete, they lose their movement and seem to become fixed in place, as if they had always been like that. The structure forgets that it could have been otherwise, and the cranes that made that provisionality possible are gone. Of course this doesn't mean that we should abandon talk of structure - how could we? - but try to build ways of thinking which can preserve its necessarily relational, temporary and mobile nature, in the moment of construction.

Futurists and constructivists found some beautiful ways of reaching towards this understanding in thinking about an aesthetics which could capture multiplicity. Boccioni was interested in 'those atmospheric planes which bind and intersect things' (1912: 114) and which would become the principle of a new form of sculpture which was predicated on a different ontology.

A piece of Futurist sculpture will contain all the marvelous mathematical and geometrical elements that constitute the objects of our age. And these objects will not be merely placed near or alongside a statue, like explanatory attributes or detached decorative elements, but, following the laws of a new conception of harmony they will be inserted inside the muscular lines of a body. In this way, the cogs of a machine might easily emerge from the armpits of a mechanic, or the lines of a table could cut a reader's head in two, or a book with its fannedout pages could intersect the reader's stomach. (op cit: 116)

Echoing Bergson, the sculpture is a space/shape brought into existence by other borrowings, or as Varvara Stepanova declared in 1921, 'Technique and industry have confronted art with the problem of construction as an active process and not a contemplative reflection. The "sanctity" of a work as a single entity is destroyed' (in Gray 2012: 289). No wonder that the form of the girder, an assemblage of lines that cuts and joins space, became such an useful way to think about relations, and to try and dethrone the 'bourgeois' fetish of the isolated work of genius. All life could be art, all materials could be understood aesthetically and the modern was distinctive because '(o)nly the straight line can lead to the primitive purity of a new architectonic structure of masses or sculptural zones.' (Boccioni 1912: 119)

The skeletal nakedness of the crane is important then, because it is an excellent example of the modernist principle of form being inextricable from function. The aesthetic of a crane is a product of what it is intended to do, in a much purer sense than of the building that they construct. As we have seen, it is quite possible to see beauty in a crane, but this is not art or ballet or architecture. An analogy with the natural sublime might be a better one, particularly as it is articulated in David Nye's 'technological sublime', which he takes to encompass bridges, dams, skyscrapers, the Apollo moon landing and so on (1994). A mountain does not intend to please, to awe, and neither does the crane. Its aesthetics are a by-product of how it moves and relates to materials, not a matter of its singularity or the 'aesthetic' intentions of its designers. Even the colour of the anti-corrosion paint on the steel, or the shape and location of the cab will have to be justified in terms of engineering or economics.

Consider this in terms of the idea of the heroic agency of the driver which, as we have seen, is something routinely denied by drivers themselves. Physical elevation often metaphorically suggests a greater degree of freedom and power, but (as a high rope access window cleaner put it in an 
interview with me) he very often just feels 'stuck up there'. Like the driver then, not free, but only able to move in particular planes and lines, depending on the structure. It is, as Tim the crane driver said, a ballet in which certain rhythmic movements are possible, but only certain ones. Consider also that such a position, stuck up there, is temporary because the modern tower crane can be disassembled, containerized, and constructed in another space with remarkable speed. It is designed to be both solid and ephemeral by turns, a spider's web which can lift masses, and moreover to be able to assemble and disassemble itself with the minimum of external intervention. Like a circus ${ }^{17}$, it can unfold itself and reveal a specific set of relations between planes and lines, a particular possibility for movement which wasn't available before. But this isn't a 'self-jacking' ontology, a form of auto-creation, because the crane is itself the construction of other relations, borrowings, intersections.

There is more than an echo of Deleuze and Guattari in my formulations here. Also influenced by Bergson, Deleuze and Guattari repeatedly offer an account of planes and lines defining space, refusing an essentialism of things or humans. I can't find any reference to Futurism or Soviet Constructivism in any of their major works $(1984,1988,1994)$ but the grammar of expression is very similar. Vladimir Tatlin called for a 'culture of materials', and thought that this radical way of connecting art and life would produce 'a new spatial form: a continually intersecting rhythm of planes whose movements jut into, cleave, embrace, block and skewer space' (Gray 2012: 181). So, in A Thousand Plateaus, do Deleuze and Guattari offer accounts of 'planes of consistency', plateaus, strata, territories and many versions of the line, rhizome, 'line of flight', diagram and so on. Later, in What is Philosophy, the key idea mutates to the 'plane of immanence' ('a table, plateau or slice' (1994: 35), as the ground from which concepts can grow. Oddly, in the same book, they do repeatedly describe themselves as 'constructivists', defining it as follows. 'Constructivism requires every creation to be a construction on a plane that gives it an autonomous existence.' (op cit: 7). This sense of constructivism stresses a world which is made, rather than discovered, but without the central place given to human agency in most of social scientific constructionism. Following Deleuze and Guattari, it is not only us humans who can be understood as causes for the production of 'assemblages', lines and planes of different speeds and viscosities (op cit: 4). For these philosophers, and for the Russian constructivists, the crane is always part of something else, produced by and producing, with its echoes of movement and lines of connection.

Describing Rodchenko and Tatlin's post-revolutionary call for 'Art into life!', a bridge between aesthetics and industry, Camilla Gray says 'The engineer must develop his feeling for materials through the method of 'Material Culture' - and the artist must learn to use the tools of mechanical production' (2012: 284). INKhUK, the post-revolutionary Institute of Artistic Culture, was an attempt to do just this. It insisted that an understanding of making something - which could be in a gallery or a factory - must include three elements 'faktura (the process of working material), tectonika (tectonics, which is based on the expedient use of industrial materials and which unites the ideological and formal), and konstrucktsia (the actual process of putting things together)' (Tupitsyn 1999: 31, also Gray 2012). In this way, the texture of materials, relations between materials and the labour process could be understood as a unity, and expressed in the product as something which was not a commodity fetish, or an expression of bourgeois individualism, capitalist exploitation and so on. In the constructivist manifesto, Gan called this 'the principle of organization', which constructivism was formulating, a way of uniting the ideological with the formal (1922: 40). 
Setting aside the question of how such production might be institutionalised, this is a remarkable theoretical demand, and one that embeds a complex theory of kaleidoscopic organization. To try and appreciate material properties, relations between materials and their conjoining in a specific form as all necessarily part of the revealing of a thing suggests multiple perspectives in the same sense that much Futurism and Constructivism tried to show the rays, angles, echoes of movement in a running man or a bicycle. This is perhaps what Anton Ehrenzweig refers to as the 'syncretic' function of art, in that it can help to de-differentiate categories of thought and experience which the adult mind holds separated (1967). The crane, it seems to me, can be a vehicle for expressing this sort of ontology beautifully, being a provisional arrangement of lines of force and planes of resistance which allow for the balletic movements of mass, money and labour. Addressing the question 'How can Art be Realised' in 1932, Alexander Calder - the engineer of mobilities - suggests the following.

'Out of different masses, light, heavy, middling -indicated by variations of size or colordirectional line-vectors which represent speeds, velocities, accelerations, forces, etc. ...these directions making between them meaningful angles, and senses, together defining one big conclusion or many.

Spaces, volumes, suggested by the smallest means in contrast to their mass, or even including them, juxtaposed, pierced by vectors, crossed by speeds.

Nothing at all of this is fixed.

Each element able to move, to stir, to oscillate, to come and go in its relationships with the other elements in its universe.'

Opening up the figure of the crane, like a window as Boccioni says, allows us to see it as a structure which temporarily constructs a set of sociotechnical relations, because the social and the material cannot be disentangled here. Like Deleuze and Guattari's 'orchid-wasp' (1988: 11), the crane requires mathematics, the welding of materials, flows of capital and labour, and (as I have shown above) it can be revealed in different ways through all of these planes too. And this is to say nothing of bees, Sulphur Crested Cockatoos and electric storms that turn the clouds green.

Whether we can 'see' cranes, or any other assemblage, in such a multiple way is a difficult question, one perhaps limited by our bodies and our imaginations, but perhaps possible with care and attention (Mol 2003). Art is clearly one way to try and do this, a method to produce strange observations, to unfold multiplicities. In David Leavitt's 1986 novel The Lost Language of Cranes, we are introduced to a neglected boy who, in the absence of human company, began to imitate the sound and actions of the cranes which he could see from his window. The speech of a crane - its creaks and whirrs - was his only language, and others, a therapist in the book, couldn't learn to speak it, though they tried. So too are planes organized in a way that allows certain lines of sight and modes of speech. Visibility works like that because there are always ways of seeing which are provided by institutions and disciplines - whether International Cranes and Specialised Transport, a Health and Safety report, a crane index, a place hacker, or Eve Weber's documentary. The intersection of these means that the crane can't be anything at all, because the lines and planes only allow for certain choreographed movements, but it can be many things, at one and the same time. The crane is a manifestation of mathematics, of engineering, of accounting, of construction, a place 
of work with sausage roll crumbs on the floor, a place of struggle which tosses in the wind, a harbinger of a world of machines, and an unnoticed source of beauty. It was with the last that this essay began, but it had to travel through all the others in order to return there again, and see that as if for the first time.

Organization theory, understood narrowly, works on a plane which intersects with the concerns of this essay, but usually only in terms of ideas about work and economics. That is because organization theorists usually work in business schools, but there is no necessary reason for that to be the case. This particular concept - organization - doesn't need to dwell in certain buildings and not others, understood as if its heart were resident in labour and finance, but not steel, mathematical calculations of stress, and Russian constructivism. I hope this essay has shifted these ideas a little, using the example of tower cranes to show that organizing can be understood in multiple ways, that understanding can be syncretic, and that these lines of sight produce a structure which is a multiple, temporary relation between different materials. Of course the same work could be done with any other assemblage too, because there's nothing special about cranes.

\section{References}

Bachman, O, Cohrs, H-H, Whiteman, T and Wislicki, A (1997) The History of Cranes. Wadhurst, East Sussex: KHL International.

Bergson, H (1911) Matter and Memory (trans by Nancy Margaret Paul and W. Scott Palmer). London: George Allen and Unwin.

Boccioni, U (1912/2009) 'Technical Manifesto of Futurist Sculpture' In Rainey, L, Poggi, C and Wittman, L (eds) Futurism: An Anthology. New Haven: Yale University Press, 113-9.

Calder, A (1932) 'Comment réaliser l'art?', Abstraction-Création, Art Non Figuratif, 1/6. (http://calder.org/life/system/downloads/texts/1932-How-Can-Art-P0337.pdf)

CPA (2008) Tower Crane Operator's Handbook. London: Construction Plant-Hire Association/Tower Crane Interest Group .

Dahm, A (2015) 'Ideal Elevation', International Cranes and Specialised Transport, April, 17-18.

Deloitte Real Estate (2015) The London Office Crane Survey: Appetite for Construction. London: Deloitte. [http://www2.deloitte.com/content/dam/Deloitte/uk/Documents/real-estate/londonoffice-crane-survey-summer-2015.pdf]

Deleuze, G and Guattari, F (1894) Anti-Oedipus: C apitalism and Schizophrenia. London: Athlone Press.

Deleuze, G and Guattari, F (1988) A Thousand Plateaus. London: Continuum.

Deleuze, G and Guattari, F (1994) What is Philosophy? London: Verso.

Ehrenzweig, A (1967) The Hidden Order of Art. Berkeley: University of California Press.

Ferguson, E (2008) 'I'm looking down on you', The Guardian, $27^{\text {th }}$ July. 
Gan (1922/1974) 'Constructivism', in S Bann (ed) The Tradition of Constructivism. New York: Viking, $32-42$.

Garrett, B (2014) Explore Everything: Place Hacking the City. London: Verso.

Glynn, J (1849) Rudimentary Treatise on the Construction of Cranes and Machinery. London: John Weale.

Gray, C (2012) The Russian Experiment in Art: 1863-1922. (Revised and enlarged by M BurleighMotley.) London: Thames and Hudson.

Helin, J, Hernes, T, Hjorth, D and Holt, R (eds) (2014) The Oxford Handbook of Process Philosophy and Organization Studies. Oxford: Oxford University Press.

Isherwood, R (2010) Tower crane incidents worldwide (Research Report RR820). Norwich: HSE Books/HMSO.

Leavitt, D (1986) The Lost Language of Cranes. New York: Knopf.

Mailer, N (1971) A Fire on the Moon. London: Pan Books.

Mol, A (2003) The Body Multiple. Durham: Duke University Press.

Nye, D. 1994. American Technological Sublime. Cambridge, MA, MIT Press.

Oliveri, F (2014) 'Acts of Citizenship against Neo-liberalism: The New Cycle of Migrant Struggles in Italy', in N-K Kim (ed) Multicultural Challenges and Sustainable Democracy in Europe and East Asia. London: Palgrave.

Parker, M (2009) 'Angelic Organization: Hierarchy and the Tyranny of Heaven' Organization Studies 30/11: 1281-1299.

Parker, M (2011) 'Organizing the Circus: The Engineering of Miracles' Organization Studies 32/4: 555 569

Parker, M (2013) ‘Containerization: Moving Things and Boxing Ideas' Mobilities 8/3: 368-387.

Parker, M (2015) 'Vertical Capitalism: Skyscrapers and Organization' Culture and Organization 21/3: 217-234.

Purdon, J (2013) ‘Pylons', Jesus College Annual Report. Cambridge: Jesus College, 24-5.

Purdon, J (2015) ‘Electric Cinema, Pylon Poetry’ Amodern 2. [http://amodern.net/]

Rainey, L, Poggi, C and Wittman, L (eds) (2009) Futurism: An Anthology. New Haven: Yale University Press.

Rorty, R (1990) Objectivity, Relativism and Truth. Cambridge: Cambridge University Press.

Sleight, C (2015) 'Olympic Lifters' International Cranes and Specialised Transport, April, 45-46.

Tisdall, C and Bozzolla, A (1996) Futurism. London: Thames and Hudson. 
Tupitsyn, M (1999) 'Back to Moscow', in M Tupitsyn (ed) El Lissitzky: Beyond the Abstract Cabinet. Yale University Press.

\footnotetext{
${ }^{1}$ Thanks to everyone who has talked to me about cranes over the past few years, but particularly the crane drivers I have interviewed (and the one high rope access worker), the officials from UCATT who helped me, and the person who let me onto the crane drivers FaceBook group. Thanks to Angus Cameron and Julia Frohn for comments on a previous draft. I wouldn't have been able to think about all this without all of you. Thanks also to the two very sympathetic reviewers for this journal.

${ }^{2}$ Almost no-one. See www.vertikal.net/en/news/story/23194/ for a house hanging from a crane in a Karlsruhe art festival.

${ }^{3}$ This is also what I have tried to do in previous work on angels, circuses, shipping containers and skyscrapers (Parker 2009, 2011, 2013, 2015), amongst other topics. All seem to concern questions of elevation and mobility too.

${ }^{4}$ Because they are, almost all, men. I was told about some women drivers, but they were rare.

${ }^{5}$ http://www.jstor.org/stable/i40060848, accessed 7/9/15

${ }^{6}$ International Cranes and Specialised Transport July 2015: 48-9.

${ }^{7}$ http://www.landsecurities.com/london-portfolio/london-property-portfolio/new-street-square, accessed $17 / 9 / 15$

${ }^{8}$ See, for example, http://www.ucatt.org.uk/construction-sites-facing-standstill-crane-drivers-ballot-industrialaction, accessed 21/7/15.

${ }^{9}$ http://www.reuters.com/article/2011/07/12/hold-korea-labour-idUSL3E7IBOVR20110712, and https://koreanstory.wordpress.com/2011/12/03/kim-jin-suk-one-things-that-saved-me-who-even-felt-likesuicidal-was/ accessed 21/7/15

${ }^{10}$ https://koreanstory.wordpress.com/2011/12/03/kim-jin-suk-one-things-that-saved-me-who-even-felt-likesuicidal-was/, written by Hur Jae-hyun, accessed 21/7/15

${ }^{11}$ http://www.gmb.org.uk/newsroom/ten-year-delay-in-battersea-crane-disaster-trial, accessed 8/9/15

12 Some of them do, though not most. The names I was told were Jane the Crane, Tinkerbell, and The Goose; together with female names such as Linda Lynne and Jenny.

${ }^{13}$ http://www.wqxr.org/\#!/story/67535-donnacha-dennehy/, accessed 17/9/15

${ }^{14}$ http://www.documentary.org/feature/meet-filmmakers-eva-weber\%E2\%80\%94-solitary-life-cranes, accessed 12/9/15

${ }^{15}$ http://www.wqxr.org/\#!/story/67535-donnacha-dennehy/, accessed 21/7/15

16 http://www.cityofcranes.com/, accessed 21/9/15

${ }^{17}$ Alexander Calder was also interested in the circus, another temporary and mobile form of organizing. See http://whitney.org/Collection/AlexanderCalder/8336195 (accessed 11/11/15, and Parker 2011).
} 